\title{
RELIEF MOTIF BURUNG MERAK PADA PESAREAN SUNAN SENDANG DUWUR PACIRAN LAMONGAN: KAJIAN BENTUK, MAKNA DAN ESTETIKA
}

HERMAN SUGIANTO

Received: 3 Oktober 2019; Accepted: 23 Oktober 2019; Published: 5 November 2019

Ed. 2019; 3 (1): 061 - 074

\begin{abstract}
This study aims to examine the relief of peacock motifs at the gate of Paduraksa I and Paduraksa II tomb complex of Sunan Sendang Duwur Paciran Lamongan which includes (1) visual relief of peacock motifs, (2) the meaning of relief of peacock motifs, and (3) aesthetic value relief of peacock motifs. This research uses descriptive qualitative methods with data collection techniques, observations, interviews, and documentation. Data analysis using sign analysis or textual analysis. The results of this study include: visual relief forms of peacock motifs at the gate of Paduraksa I and Paduraksa II at the Sunan Sendang Duwur tomb are ornaments with a floristic style that has undergone Islamization, namely the shape of ornamentation informed of the flora motif into the shape of a peacock animal. The meaning of relief in the tomb complex of Sunan Sendang Duwur basically gives a picture of how human relations with humans, human relations with nature and the relationship between humans and their Lord. This relief also provides a description of the symbols of life that is about courage, knowledge, protection, protection, greatness, strength and justice. This relief also gives us an idea that this tomb complex is a gathering of holy spirits, the final resting place from human to human journey to face God in another sense that the Sunan Sendang Duwur tomb complex is a sacred/sacred place, so we must not carelessly take action or acts that violate the applicable ethics. The aesthetic values contained in the reliefs in the tomb complex of Sunan Sendang Duwur, which is a picture of a journey to holiness and also a picture of the division of nature, that is physical, spiritual and conscience. From the analysis it can be concluded that the relief of the tomb complex of Sunan Sendang Duwur has a form of ornamentation with a floristic style that is Islamized both in terms of visual form, meaning and aesthetic values contained therein connected with Islamic teachings in the form of the teachings about God.
\end{abstract}

Key words: relief, peacock motifs, study of forms, study of meaning, study of aesthetic.

\section{PENDAHULUAN}

Komplek makam yang sekarang menjadi fenomena di masyarakat yaitu komplek makam yang dikeramatkan, seperti para wali, danyang, dan tokoh masyarakat yang memiliki pengaruh kuat, dibanding berziarah atau berkunjung ke kompleks pemakaman keluarga. Beberapa makam wali yang terdapat di Jawa Timur menjadi destinasi wisata religi masyarakat antara lain: Sunan Ampel di Surabaya, Sunan Gresik, Sunan Maulana Malik Ibrahim di Gresik, Sunan Derajat di Lamongan dan Sunan Bonang di Tuban. Kompleks pesarean di beberapa tokoh utama 9 wali hampir memiliki kesamaan, baik dari segi bangunan arsitekturnya, ataupun dari penataan makamnya. Hal ini berbeda dengan 
salah satu kompleks pesarean di sebuah daerah perbatasan kabupaten Tuban tepatnya di Desa Sendang Duwur Kecamatan Paciran Lamongan. Pada komplek pesarean ini terdapat bangunan makam atau pesarean seorang Waliyullah yaitu Sunan Sendang Duwur. Komplek pesarean Sunan Sendang Duwur memiliki kekhasan sendiri dibanding dengan komplek pesarean para wali yang lain yaitu adanya nuansa atau pengaruh agama Hindu. Pada makam ini terdapat dua macam gapura yang berbentuk menyerupai candi, yaitu gapura Candi Bentar dan gapura Kori Agung (Paduraksa). Kedua gapura ini merupakan gapura yang biasa terdapat pada candi agama Hindu, seperti dapat kita jumpai di daerah Bali.

Selain bentuk keindahan dari seni arsitektur gapura pada komplek pesarean, terdapat pula karya seni rupa yaitu seni relief. Relief adalah karya seni dua dimensi yang cara pengerjaannya dengan dipahat, media yang digunakan biasanya menggunakan batu alam. Berdasarkan jenisnya relief terdapat dua jenis relief yaitu relief flora dan relief fauna. Sedangkan kalau dilihat dari temanya terdapat dua jenis bentuk relief, yaitu relief cerita dan relief non cerita. Hiasan yang ada di Candi, antara lain adalah area, hiasanhiasan struktural (seperti pelipit), serta reliefrelief. Ditinjau dari temanya, terdapat dua jenis relief, yaitu relief cerita dan non cerita. Relief cerita dapat ditemukan antara lain di Candi Borobudur yang menceritakan perjalanan Budha Gautama dan naskah jataka, serta di Candi Mendut dan Sojiwan (Klaten) dengan cerita binatang, sedangkan relief non cerita berupa penggambaran apsara atau tokoh tertentu lainnya, tetumbuhan seperti ceplok bunga, pohon, seuluran, binatang, serta goresan-goresan geometris (SUMiATI AtMOSUDIRO dkk, 2008: 167-168).

Relief yang terdapat pada dinding komplek pesarean Sunan Sendang Duwur ditinjau dari temanya termasuk dalam katagori relief non cerita. Relief non cerita di jumpai di setiap dinding gapura yang berupa flora seperti stilasi daun, tumbuh-tumbuhan dan relief dengan bentuk singa bersayap, burung merak, labalaba, naga, ular, rusa, burung, dan sayap burung Garuda, hal ini berdasarkan pengamatan awal peneliti ke kawasan kompleks pesarean. Hal yang menarik juga pada relief di kompleks pesarean Sunan Sendang Duwur yaitu relief dengan bentuk binatang yang lebih diabstrakkan karena bentuknya tidak merupakan wujud asli dari binatang akan tetapi merupakan stilasi daun atau flora yang dirangkai hingga membentuk sebuah wujud binatang. Selain itu ada bagian relief yang pembuatannya tidak sampai selesai yaitu pada salah satu bagian sayap gapura burung garuda di area utama atau area ketiga dan pada bagian atas gapura paduraksa di area pertama. Relief yang terdapat pada dinding gapura kompleks pesarean terbagi dalam tiga halaman masing-masing halaman memiliki berbagai bentuk motif yang berbeda, walaupun terdapat pengulangan bentuk motif namun penempatan dari masing motif pada tiap panel berbeda.

UKA TJANDRASASMITA (1975), yang dibukukan dengan judul "Islamic Antiquities of Sendang Duwur". Pada penelitian ini juga dijelaskan bahwa seni arsitektur dan seni dekoratif kompleks pesarean Sunan Sendang Duwur sangat mirip dengan seni yang berasal dari Mantingan Jepara. ini bisa disebabkan fakta bagian-bagian tertentu dari monumen, terutama pada panel yang diukir, hal ini memberikan pesepsi bahwa kemungkinan pengukir dari Mantingan diundang untuk mengerjakan relief yang ada di Sendang duwur. Akan tetapi kemungkinan lain adalah bahwa penduduk dari Sendang Duwur belajar kerajinan di Mantingan dan kembali ke desa mereka untuk pembangunan masjid dan bangunan lainnya. Namun, dari beberapa bangunan di Sendang Duwur seperti gerbang bersayap yang sangat 
mungkin dibuat oleh pengrajin dari desa sebagai unsur tidak ditemukan di tempat-tempat lain di terdapat kreasi dari periode Hindu-Indonesia. Penelitian ini juga menjelaskan unsur-unsur tertentu dari motif hias yang tidak ditemukan di Mantingan seperti marga kala, pohon kehidupan, merak, garuda dan beberapa objek lainnya adalah bukti bahwa seniman dari Sendang Duwur masih melanjutkan tradisi Hindu atau tradisi asli.

Motif burung merak merupakan salah satu dari berbagai motif fauna yang terdapat di pesarean Sunan Sendang Duwur, motif ini terdapat pada halaman pertama yang terletak pada dinding gapura Paduraksa I dan gapura Paduraksa II. Pada komplek pesarean, motif burung merak sudah dikenali pada nekara peninggalan prasejarah. Burung merak tinggal di hutan memiliki bentuk dan warna yang indah. Ekornya yang panjang dan digambarkan dalam keadaan terbuka dengan pola bulatan pada bulu ekornya merupakan ciri yang menonjol. Ciri yang lain adalah leher yang panjang dengan kepala berjambul. Bentuknya yang sangat indah sangat menarik jika dijadikan motif hiasan. Dalam agama Hindu, burung merak dipandang sebagai wahana dewa perang, yakni dewa Skanda atau Kartikeya, juga kendaraan Parwati ibunya. Selain sebagai lambang dunia atas burung merak sebagai lambang kesucian. SUNARYO (2009: 68). Pada kajian ini lebih fokus pada relief dengan motif burung merak -yang terdapat pada gapura Paduraksa halaman pertama yang terdiri dari dua gapura Paduraksa, gapura Paduraksa pertama yaitu gapura yang memiliki ukuran lebih kecil, gapura ini menghubungkan halaman pertama dengan makam yang terdapat pada halaman pertama yang berada disebelah kiri halaman pertama. Gapura Paduraksa kedua memiliki ukuran lebih besar yang menghubungkan halaman pertama dengan halaman kedua komplek pemakaman Sunan Sendang Duwur ditinjau dari kajian bentuk, makna dan estetikanya.
Peneliti menggunakan pendekatan deskriftif kualitatif, yaitu suatu penelitian yang diambil dari pendapat orang-orang serta prilakunya yang menghasilkan data deskriftif baik berupa katakata tertulis maupun lisan. Penelitian deskriftif kualitatif tidak mencari atau menjelaskan hubungan, tidak menguji hipotesis atau membuat prediksi melainkan bertujuan membuat deskripsi yang secara sistematis, faktual dan akurat (KRISYANTONO, 2006: 69)

\section{DASAR TEORITIS}

\section{Bentuk Visual Relief}

Bentuk adalah gambaran, rupa atau wujud, sistem atau susunan, serta wujud yang ditampilkan. (Kamus Besar Bahasa Indonesia: 1995: 119). Bentuk yang paling sederhana adalah titik. Titik tersendiri tidak mempunyai ukuran atau dimensi. Titik sendiri belum memiliki arti tertentu. Kumpulan dari beberapa titik akan mempunyai arti dengan menempatkan titik itu secara tertentu. kalau titik-titik berkumpul dekat sekali dalam suatu lintasan, mereka bersama menjadi bentuk garis. Beberapa garis bersama bisa membentuk bidang. Beberapa bidang bersama menjadi bentuk ruang. Titik, garis, bidang dan ruang merupakan bentukbentuk mendasar bagi seni rupa. DJELANTIK (1999: 21).

\section{SUSANE K. LANGER menyebutkan seni} sebagai bentuk harus merupakan satu kebulatan yang organis, tidak ada yang berdiri sendiri melainkan bersama-sama dengan bagian yang lainnya, LARNGER (1957: 27). Raut adalah ciri khas suatu bentuk. Bentuk apa saja dialam ini tentu memiliki raut yang merupakan ciri khas dari bentuk tersebut. Bentuk titik, garis, bidang, dan gempal, masing-masing memiliki raut. Raut merupakan ciri khas untuk membedakan masing-masing bentuk dari titik, garis, bidang, gempal tersebut. SANYOTO (2010: 83). 


\section{Pemaknaan Bentuk Gapura}

SUNARTO (1991: 43) berpendapat bahwa pintu gerbang gunungan wayang kulit purwa ini menggambarkan suatu tempat untuk masuk ke alam gelap gulita, dan merupakan batas alam padang (alam fana) dan alam baka, suatu simbolisasi dari akhir kehidupan. Dalam usaha melangkah ke alam gelap tidak ada yang dapat membantu kecuali nuraninya sendiri dan amal perbuatan baik yang telah dilakukan di alam fana. Alam gelap gulita merupakan suatu tempat yang dapat dikatakan tan kena kinaya ngapa, yang artinya yang tidak dapat dibayangkan wujudnya dengan apapun.

Pintu gerbang melambangkan atau menyimbolkan batas alam dunia dengan alam adikodrati, yang dalam wayang disebut kahyangan. Alam di luar istana merupakan makkrokosmos, sedangkan yang berada di dalam pintu gerbang merupakan mikrokosmos. Di dalam istana merupakan tempat para dewa. Dewa adalah roh yang dianggap suci atau dipercayai sebagai penguasa atas alam dan manusia, RADHITA YUKA (2009: 30).

Menurut SASTROAMIDJOJO (1964: 203) menyatakan bahwa pintu gerbang dengan jenjang bertingkat, melambangkan pintu masuk dari alam fana ke alam baka, terpisahnya roh dan raga. Sedangkan jenjang bertingkat melambangkan jalan penuntun agar manusia mentaati tuntutan agama. Dari uraian di atas dapat dinyatakan bahwa pintu gerbang atau gapura merupakan batas antara alam dunia dan alam akhirat, alam fana ke alam baka serta terpisahnya roh dan raga.

\section{Konsep Makna}

Makna merupakan hasil dari pengalaman budaya masyarakat yang berlaku sesuai dengan nilainilai kebudayaannya. Makna adalah nama yang diberikan pada berbagai hubungan dalam interaksi yang terjalin. Makna bukan proyeksi pikiran atau obyek melainkan persepsi suatu hubungan riil di dalam suatu kaitan yang mendahului pemisahan-pemisahan objek-obyek di dalam pikiran. Jadi dalam pemahaman makna benar-benar memasuki suatu hubungan riil dengan bentuk-bentuk ekspresi yang nyata, dengan demikian nampak adanya suatu lingkaran de facto yang saling berinteraksi dan makna tiada lain adalah nama yang diberikan kepada berbagai hubungan dalam interaksi tersebut. (HENDRIYANA, 2009).

\section{Teori Estetika}

Monroe Beardsley dalam Problems in the Philosophy of Criticim dalam DHARSONO (2007: 95) yang menjelaskan adanya tiga ciri yang menjadi sifat-sifat membuat baik (indah) dari benda-benda estetis pada umunya. Ketiga ciri tersebut ialah:

a. Kesatuan (unity) ini berarti bahwa benda estetis ini tersusun secara baik atau sempurna bentuknya.

b. Kerumitan (complexity) benda estetis atau karya seni yang besangkutan tidak sederhana sekali, melainkan kaya akan isi maupun unsurunsur yang saling berlawanan ataupun mengandung perbedaan-perbedaan yang halus.

c. Kesungguhan (intensity) suatu benda estetis yang baik harus mempunyai suatu kualitas tertentu yang menonjol dan bukan sekedar sesuatu yang kosong. Tak menjadi soal kualitas apa yang dikandungnya (misal suasana suram atau gembira, sifat lembut atau kasar), asal merupakan sesuatu yang intensif atau sungguh-sunguh.

\section{a.Konsep Estetika Jawa}

Menurut DHARSONO (2007: 146) menyatakan bahwa rangkaian bentuk estetika nusantara (Jawa), diimplementasikan lewat 
sugesti alam. Jadi tidak mengherankan apabila masyarakat klasik saat itu di dalam usahanya untuk mendekatkan kita terhadap Tuhannya dengan cara mendekatkan dirinya dengan alam semestanya. Sehingga terjadi hubungan antara dirinya (mikrokosmos) dengan alam semesta dan lingkungannya (makrokosmos) dan hubungan antara dirinya dengan Tuhannya. Pandangan orang Jawa dalam melihat, memahami, dan berprilaku juga berorientasi terhadap budaya sumber. "Proses budaya Jawa selaras dengan dinamika masyarakat yang mengacu pada konsep budaya induk, yaitu "sangkan paraning dumadi“. Konsep tersebut dalam budaya Jawa dikenal dengan istilah nungggak semi.

Orang Jawa dalam falsafahnya yang menggambarkan sisi kehidupan dengan tiga macam jagad (Tri-Loka/Tribuana), yaitu hubungan antara tiga (3) jagad atas (alam niskala), jagad tengah (alam niskala-sakala), dan jagad bawah (alam sakala), merupakan tiga jagad untuk menjaga keseimbangan secara horisontal dan vertikal. Secara horisontal menjaga keseimbangan antara dirinya dengan alam semesta dan secara vertikal menjaga keseimbangan terhadap ke-Esa-an (hubungan mikrokosmos dan makkrokosmos).

DHARSONO (2007: 162).

\section{b. Konsep Estetika Islam}

Seni rupa Islam di Indonesia pada tahap awal merupakan hasil penerapan tradisi seni Islam Hindu sesuai dengan fungsi dan kaidah seni baru. Agama Islam sebagai nilai budaya baru di Indonesia memang tidak banyak memberi citra baru dibidang seni rupa pada masa awal perkembangannya. SUDARSONO, dkk (2012: 36). Abay D. Subarna dalam SUDARSONO, dkk (2012: 37) menyatakan bahwa unsur simbolik dan estetika dalam bangunan Islam di Indonesia, merupakan pencerminan dari nafas kebudayaan di suatu daerah. Besar atau kecilnya peranan budaya lokal, berbobot atau tidaknyakarya seni rupa pra-Islam, itulah yang mewarnai bentuk kesenian Islam termasuk perwujudan arsitekturnya. Ketergantungan pada ruang dan waktu inilah yang menghasilkan keaneka-ragaman gaya dan coraknya, sehingga dalam meneliti mengenai bentuk estetik dan makna simbolnyapun patut memperhatikan sejumlah faktor yang mempengaruhi watak dan identitas bangunan tersebut. Faktor-faktor penentu tersebut antara lain: (1) peranan unsur lokal atau warisan budaya pra-Islam yang berkesinambungan pada masa Islam, (2) Interpretasi dan titik tolak yang berbeda-beda terhadap Hadist-Hadist Nabi yang berkaitan dengan seni rupa, dan (3) arti simbolik dan bentuk estetika.

Ahmad Muhammad Is a dalam M ABDUL JABBAR (2012: 42) menyatakan bahwa dalam pembicaraan mengenai estetika Islam ada hal yang patut mendapat perhatian yaitu berhubungan dengan interpretasi dan titik tolak yang berbeda-beda terhadap Hadist-hadist Nabi yang berkaitan dengan seni rupa, yakni terkait penggambaran mahluk hidup bernyawa (tashwir). Islam melarang pembuatan lukisan dan patung mahluk hidup. Tetapi sebenarnya tidak terdapat petunjuk bahwa bentuk seni sepenuhnya diharamkan dalam masyarakat Islam terdahulu. Al Qur'an sendiri tidak mengatur hal-hal yang berhubungan dengan seni lukis, tetapi dalam sunah Rasul atau hadist, ada beberapa hadist yang menentang pembuatan gambar atau pembuatan mahluk hidup. Akan tettapi hadis-hadis ini yang menjadi sumber berbagai penafsiran. Hadist-hadist itu adalah: (1) "Malaikat tidak akan memasuki rumah yang di dalamnya ada gambar (tashwir) atau anjing." Dan hadist yang berbunyi "Orang-orang yang akan mendapat siksaan yang sangat pedih pada hari kiamat adalah para pembuat gambar mahluk hidup (mushawwirun).“ 


\section{c. Kosmologi Budaya Hindu}

HENDRIYANA dalam FEMI (2015: 29) menyatakan bahwa nilai-nilai budaya Hindu hingga kini akrab dan melebur dalam kesenian tradisional di Indonesia baik itu sebagai inspirasi maupun sebagai bentuk simbolik aplikasi nilainilai ritual budaya. Dalam konsep primodial Hindu terkadang makna konsep ruang dalam keseimbangan kosmos (balance cosmologi). Dalam hal ini ruang makro (alam raya) senantiasa harus seimbang dengan ruang mikro (alam manusia). Di dalam mikrokosmos terdapat tiga unsur ruang secara vertikal yang dianalogikan sebagai tiga dunia (Tribhuawana). Struktur ruang tribhuwana ini terdiri dari: (1) bumi dan lingkungan sebagai alam paling bawah, disebut Bhurloka, (2) alam tengah adalah alam roh-roh suci, disebut (Bhuwarloka), (3) alam atas alam para Dewa, disebut (Swarloka).

HASIL KAJIAN DAN PEMBAHASAN A. Bentuk Visual Relief Motif Burung Merak pada Gapura Paduraksa Halaman Pertama Kompleks Pesarean Sunan Sendang Duwur

\section{Gapura Paduraksa I}

Gapura Paduraksa I merupakan salah satu gapura yang terletak di halaman pertama komplek pesarean Sunan Sendang Duwur sebagai pintu masuk dari halaman pertama menuju makam-makam yang berada di samping kiri halaman pertama. Gapura I ini memiliki ukuran yang lebih kecil jika dibandingkan dengan gapura lainnya, serta memiliki jumlah panil dengan jenis relief yang lebih sedikit yaitu dengan tiga panil, dimana panil 1 dan panil 3 memiliki motif yang sama, sedangkan pada panil 2 memiliki motif yang berbeda dan salah satu motif yang ada pada panil 2 yakni motif burung merak.

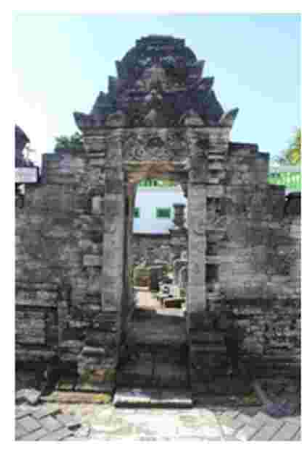

Gambar 1. gapura paduraksa I (foto koleksi pribadi 2018)

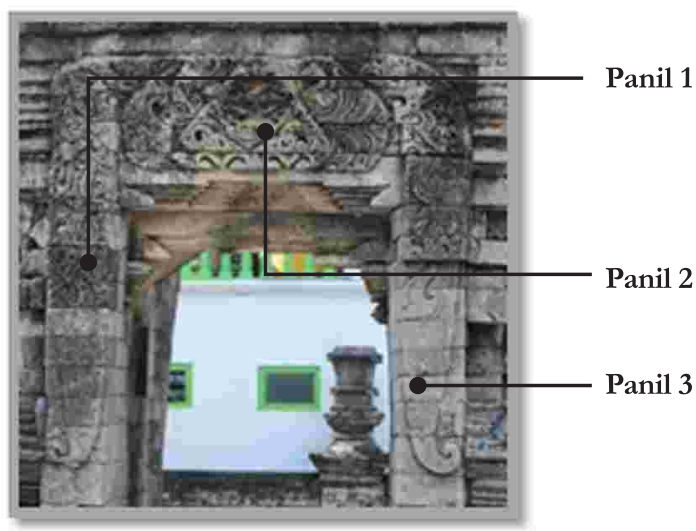

Gambar 2. bagian gapura I yang memiliki panil pada dindingnya (sumber foto koleksi pribadi 2018).

Bentuk visual pada panil gapura I terbagi menjadi menjadi tiga panil, yaitu panil 1, panil 2 dan panil 3, panil 1dan panil 3 memiliki bentuk dan motif yang sama, sehingga pengkajian bentuk visual relief dijadikan satu, sedangkan panil 3 terdapat pada bagian atas diantara sisi panil 1 dan panil 2.
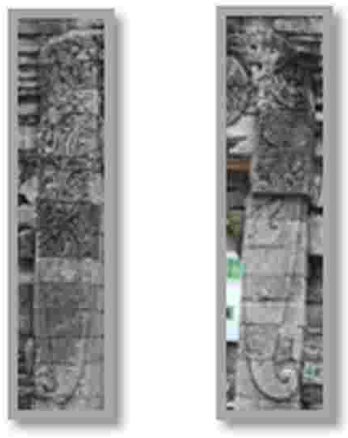

Gambar 3.

Panil 1 dan panil 3

(foto koleksi pribadi 2018) 
Bentuk visual relief pada panil 1 dan 3 ini merupakan stilasi dari daun yang terdiri dari daun pokok ikal pada bagian ujung bawah, terdapat angkup dan jambul susun pada daun pokok ikal kedua, pada bagian atas pokok ikal tersusun dari motif-motif daun dengan ujung daun berbentuk ikal, yang merupakan ciri dari motif Majapahit. Bentuk relief tiang gapura ini didistorsikan membentuk sebuah karakter belalai gajah dengan penempatan stilasi pokok ikal pada bagian bawah ornamen. Sehingga penekanan karakter belalai gajah terlihat jelas. Bentuk relief tiang gapura ini ditransformasi dari stilasi bentuk daun yang digabung menjadi satu membentuk motif belalai gajah.Bentuk motif belalai gajah merupakan perwakilan dari bentuk binatang gajah secara utuh, jadi bentuk visual relief pada panil 1 dan 3 merupakan jenis motif fauna (belalai gajah) dengan gaya floristik yang terbentuk dari stilasi dari daun pokok ikal, terdapat angkup dan jambul, pada tiap-tiap ujung daun berbentuk ikal, penekanan karakter dari motif belalai gajah telihat pada bagian pokok daun ikal. Belali gajah merupakan perwakilan dari bentuk gajah sempurna. Motif ini dipengaruhi oleh motif Majapahit.

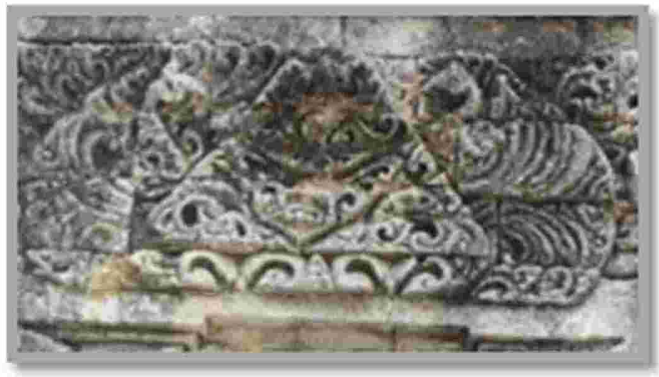

Gambar 4. panil 2

(sumber foto koleksi pribadi 2018)

Bentuk visual relief pada panil 2 ini terbagi menjadi tiga bagian, bagian tengah yang berbentuk segitiga atau gunung merupakan stilasi dari daun yang setiap ujung daun berbentuk ukel, pada bagian kedua dan ketiga berada pada pinggir samping kiri dan kanan gunung terdapat dua motif burung merak yang distilasikan dari motif daun, pada ujung daun berbentuk ukel. Bentuk relief ini mengalami proses disitorsi yaitu dengan penekanan dari stilasi daun menjadi karakter gunung atau benda alam, dan penekanan dari stilasi daun menjadi karakter burung merak. Bentuk gunung ditransformasikan dari Stilasi bentuk daun yang disusun sehingga membentuk sebuah motif segitiga atau gunung, bentuk burung merak ditransformasikan dari stilasi daun sehingga membentuk motif burung merak. Keduan bentuk relief ini tidak mengalami proses disformasi, karena kedua bentuk itu merupakan wujud nyata dari gunung dan burung merak. Berdasarkan analisis di atas Bentuk visual pada panil 2 terdapat dua motif yaitu relief dengan motif alam (gunung) dan relief dengan motif fauna (burung merak) dengan gaya floristik yaitu kedua motif itu terbentuk dari stilasi daun.

\section{Gapura Paduraksa Kedua}

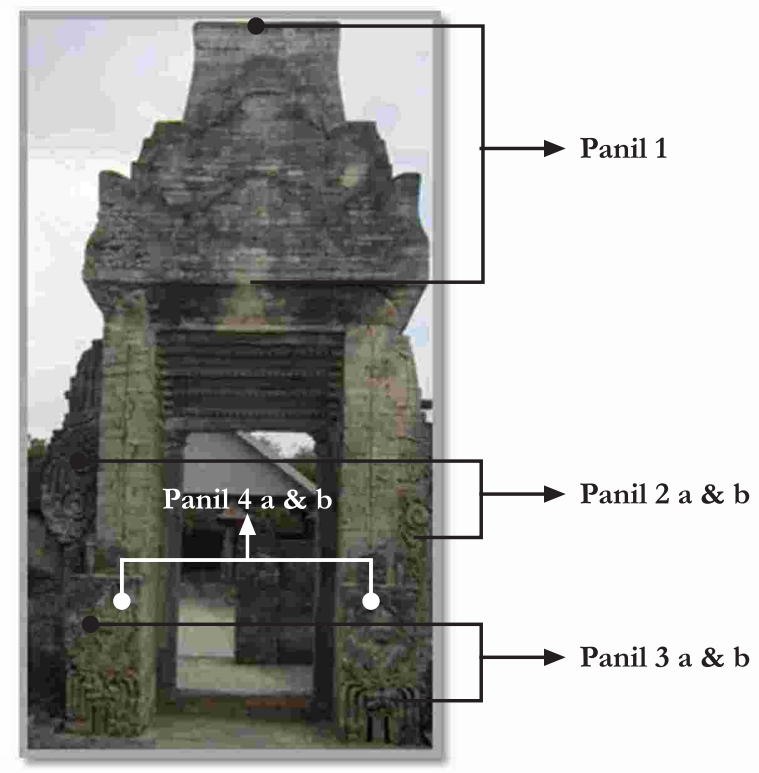

Gambar 5. gapura Paduraksa II. (sumber foto koleksi pribadi 2018)

Pada gapura Paduraksa II terbagi menjadi enam panil dimana masing panil terdiri dari beberapa motif yang berbeda, pada panil 1 terdapat pada bagian atas panil yang disebut meru. Panil 2a dan panil $2 \mathrm{~b}$ memiliki bentuk relief dengan 
motif dan karakter yang sama yang terdapat pada bagian samping dinding gapura, panil $3 a$ dan $3 b$ juga memiliki bentuk dan jenis motif yang sama juga terdapat pada bagian samping dinding gapura dan berada dibawah panil $2 \mathrm{a}$ dan $2 b$. sedangkan panil $4 a$ dan $4 b$ yang terdapat pada bagian kaki gapura pada bagian depan yang memiliki motif dan karakter yang sama dan pada panil ini terdapat motif burung merak yang dijadikan obyek penelitian.

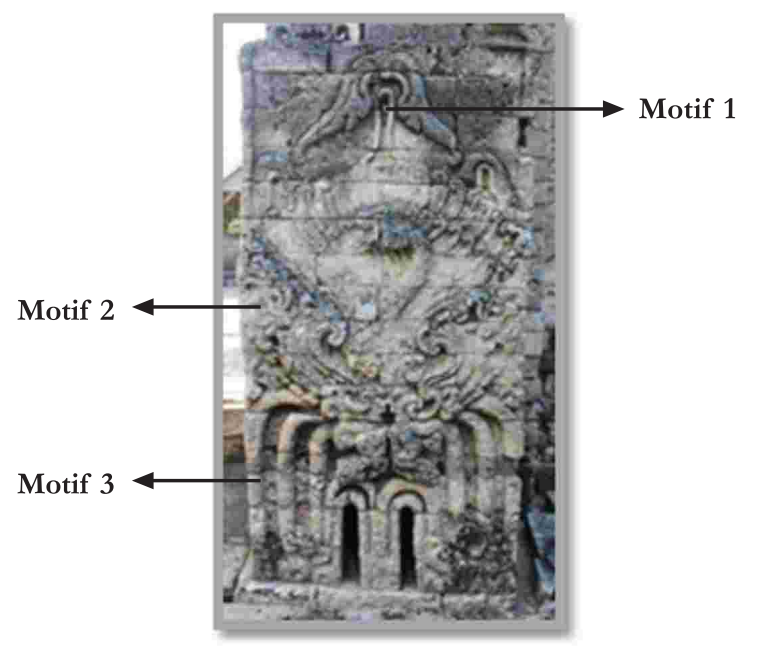

Gambar 6. Panil 4 (panil 4a dan panil 4b) (sumber foto koleksi pribadi 2018).

Panil 4 terdapat tiga motif yang berbeda yaitu, relief dengan motif gunung, relief dengan motif burung merak dan relief dengan motif gapura. Motif satu berupa relief dengan motif gunung yang distilasikan dengan hiasan daun dan motif ukel yang menghiasi bentuk gunungan tersebut. Karakter yang menonjol dari relief ini adalah bentuk gunungan yang berasal dari bentuk dasar segitiga. Relief ini mengalami transformasi, yaitu bentuk daun dan ukel yang membentuk gunungan. Tidak mengalami disformasi. Motif dua berupa relief dengan motif burung merak dihias dengan stilasi-stilasi ornamen yaitu diantanranya motif ukelan, dedaunan pada bentuk merak. Karakter yang ditonjolkan dari relief ini yaitu bentuk burung merak. Mengalami transformasi yaitu berupa stilasi daun dan ukel yang dibentuk menjadi burung merak. Tidak mengalami disformasi. Relief dengan motifurung merak ini terdapat di sebelah kanan dan kiri gapura. Motif ketiga yaitu relief dengan motif gapura, relief ini merupakan stilasi dari garis yang melengkung membentuk sebuah gapura yang memiliki pintu dua, penekan karakter pada relief ini garis lengkung dan lubang yang yang memperkuat bahwa bentuk ini merupakan sebuah gapura. Jadi bentuk visual relief panil 4 berupa relief dengan motif alam yang berbentuk gunung, relief dengan motif flora yang berbentuk burung merek dan relief dengan motif teknologi yang berbentuk gapura.

\section{B. Makna Relief Motif Burung Merak pada Gapura Paduraksa Halaman Pertama}

\section{Kompleks Pesarean Sunan Sendang Duwur Paciran Lamongan}

1. Makna Relief pada Panil yang Terdapat di Gapura Paduraksa I

Gapura Paduraksa I pada halaman pertama memiliki tiga panil, dimana panil 1 dan panil 2 memiliki bentuk dan karakter yang sama sehingga peneliti mengkaji menjadi satu kajian.

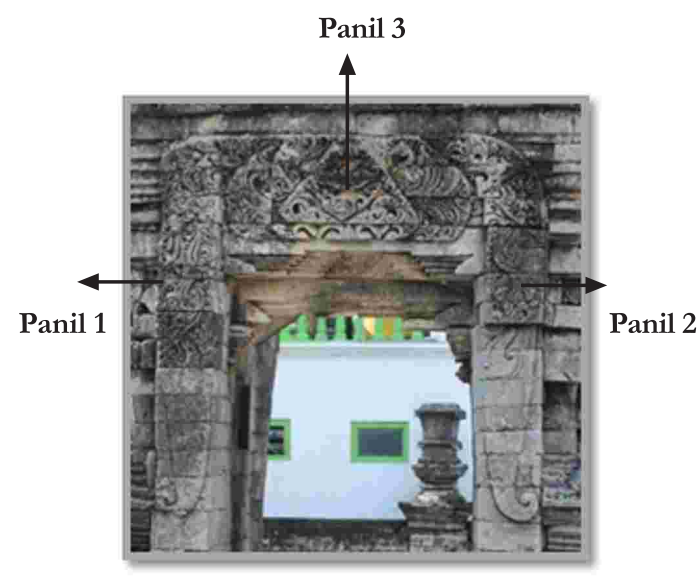

Gambar 7. Gapura paduraksa I (sumber foto koleksi pribadi 2018) 
Relief pada Panil 1 dan panil dua merupakan stilasi daun dengan motif fauna yang membentuk sebuah belalai gajah, motif belalai mewakili motif gajah secara keseluruhan. Relief dengan bentuk gajah memiliki makna konotasi sebagai lambang kebijaksanaan, ilmu pengetahuan, kebesaran, kekuatan dan keadilan hukum. Gajah merupakan kendaran roh nenek moyang atau perwujudan dari dewa Ganesha. Relief bentuk gajah memiliki mitos sebagai binatang suci. Berdasarkan paparan diatas Relief dengan dengan bentuk belalai gajah sebagai perwakilan binatang gajah secara keseluruhan memiliki makna lambang kebijaksanaan, ilmu pengetahuan, kebesaran, kekuatan dan keadilan. Relief ini merupakan simbol perwujudan dari dewa Ganesha dan roh para nenek moyang.

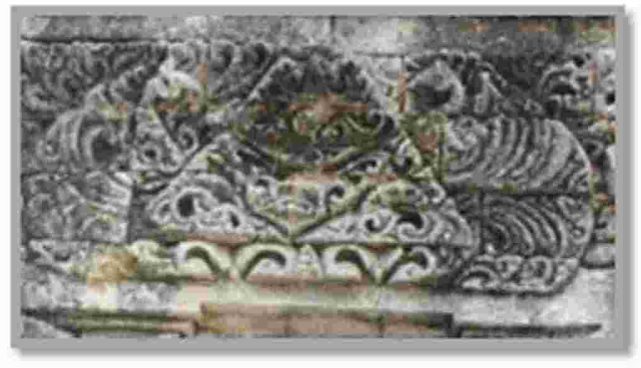

Gambar 8. Panil 3

(sumber foto koleksi pribadi 2018)

Relief pada panil 3 memiliki tiga bentuk motif yaitu motif alam dalam bentuk gunung dan dua motif fauna dengan bentuk sepasang burung merak. Bentuk gunung merupakan bukit yang sangat besar dan tinggi (biasanya tingginya lebih dari $600 \mathrm{~m}$ ) sedangkan burung merak adalah burung yang kepalanya kecil dengan leher panjang serta memiliki bulu yang indah. Gunung memiliki makna konotasi yaitu tempat pemujaan terhadap nenek moyang, juga gunung melambangkan bumi atau tanah, gunung merupakan tempat tinggal para roh nenek moyang, gunung merupakan tempat para dewa. Burung merak Dalam agama Hindu, dipandang sebagai wahana dewa perang, yakni dewa Skanda atau Kartikeya, juga kendaraan Parwati ibunya. Gunung memiliki mitos sebagai tempat suci, sedangkan burung merak memiliki mitos burung suci dan lambang dunia atas, jadi relief dengan bentuk gunung dan sepasang burung merak yang berada di samping kiri samping kanan memiliki makna bahwasanya gunung sebagai tempat suci yang dalam kepercayan dulu merupakan tempat roh nenek moyang sedangkan dalam agama Hindu merupakan tempat tinggal para dewa dan juga sebagai lambang bumi atau tanah. Burung merak dengan posisi di samping kiri dan kanan memiliki makna bahwasanya burung suci dan lambang dari dunia atas ini sebagai penjaga tempat suci.

\section{Makna Relief pada Panil yang Terdapat di Gapura Paduraksa II}

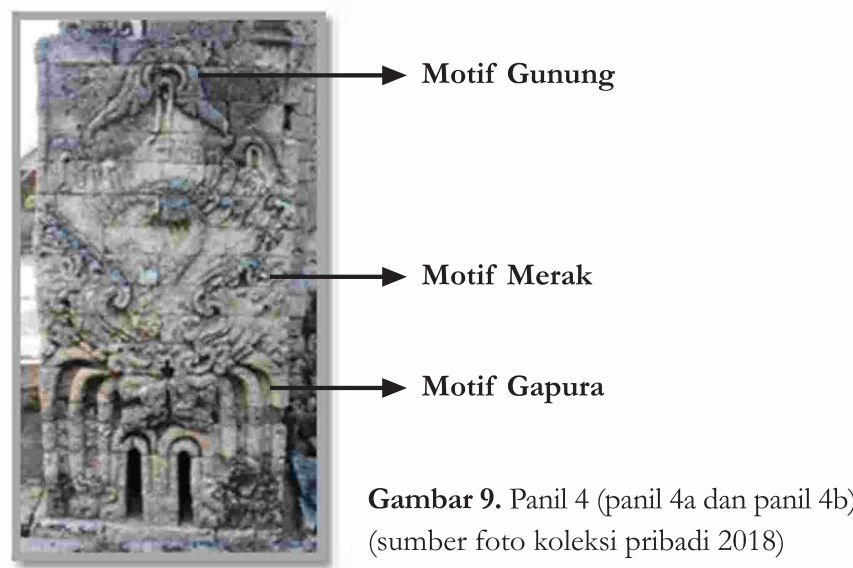

Pada panil 4 terdapat tiga motif yaitu motif alam dengan bentuk gunung, motif fauna dengan bentuk burung mereak dan motif teknologi dengan bentuk gapura. Gunung merupakan bukit yang sangat besar dan tinggi burung merak dan gapura, burung merak adalah burung yang kepalanya kecil dengan leher panjang serta memiliki bulu yang indah. Relief dalam bentuk gapura, gapura merupakan pintu besar untuk masuk kepekarangan rumah, Gunung memiliki makna tempat pemujaan terhadap nenek moyang., melambangkan bumi atau tanah. gunung merupakan tempat tinggal para roh nenek moyang, burung merak dalam agama Hindu, sebagai wahana dewa perang, yakni dewa Skanda atau Kartikeya, juga 
kendaraan Parwati ibunya. Pintu gerbang atau gapura melambangkan batas alam dunia dengan alam adikodrati, yang disebut kahyangan. Alam diluar istana merupakan makkrokosmos, sedangkan yang berada di dalam pintu gerbang merupakan mikrokosmos. Didalam istana merupakan tempat para dewa. Dewa adalah roh yang dianggap suci atau dipercayai sebagai penguasa atas alam dan manusia. pintu gerbang dengan jenjang bertingkat, melambangkan pintu masuk dari alam fana ke alam baka, terpisahnya roh dan raga. Sedangkan jenjang bertingkat melambangkan jalan penuntun agar manusia mentaati tuntutan agama. Gunung merupakan tempat suci, burung merak sebagai hewan suci, Gapura merupakan pintu pembatas dua alam. Relief dengan motif gunung dan pohon hayat memiliki makna bahwasanya gunung sebagai tempat suci, tempat para dewa dan roh nenek moyang, Burung merak dengan posisi di samping kiri dan kanan memiliki makna bahwasanya burung suci dan lambang dari dunia atas ini merupakan penjaga tempat suci ini. Relief bentuk gapura memiliki makna sebagai pintu batas alam dunia (makrokosmos) dengan alam adikodrati (mikrokosmos), gapura juga melambangkan pintu masuk dari alam fana ke alam baka, terpisahnya roh dan raga, Sedangkan jenjang bertingkat melambangkan jalan penuntun agar manusia mentaati tuntutan agama.

\section{Nilai Estetika Relief Motif Burung Merak pada Gapura Paduraksa Halaman Pertama Kompleks Pesarean Sunan Sendang Duwur Paciran Lamongan}

\section{Nilai Estetika pada Panil Gapura Paduraksa I}

Relief pada panil di gapura paduraksa I terdapat tiga panil, dimana panil 1 dan panil 2 memiliki bentuk dan karakter yang sama. Proses menganalisis panil ini dijadikan satu kajian karena ketiga panil tersebut merupakan satu kesatuan cerita, sehingga tidak bisa di kaji secara terpisah-pisah.

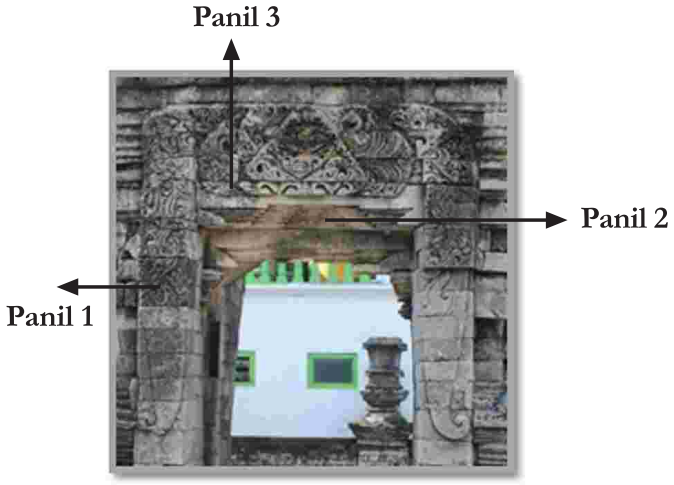

Gambar 10 Gapura paduraksa I (sumber foto koleksi pribadi 2018)

Unsur kesatuan relief pada panil di gapura paduraksa I yaitu, unsur garis lengkung yang dominan membentuk menjadi unsur bangun melalui proses stilasi menjadi sebuah bentuk motif yaitu bentuk belalai yang merupakan perwujudan dari bintang gajah, bentuk gunung dan bentuk sepasang burung merak, dengan tekstur alami. Perpaduan sepasang bentuk belalai gajah (motif gajah) dengan sepasang burung merak yang berada disamping kanan dan kiri bentuk gunung, memberikan gambaran sebuah ruang semu yaitu sebuah perjalan manusia menuju ke alam kesucian dan pembagian tiga alam.

Unsur kerumitan relief pada panil di gapura paduraksa I yaitu, Relief ini merupakan perpaduan dua unsur yang berbeda, yaitu agama Hindu dengan Islam. Bentuk belalai (gajah) dalam agama Hindu merupakan simbul dari dewa Ganesha, bentuk burung merak dalam agam Hindu merupakan kendaraan dari dewa Skanda atau Kartikeya, juga kendaraan Parwati ibunya, sedangkan bentuk gunung dalam agama Hindu merupakan perwujudan gunung Mahameru yang merupakan tempat para dewa, ketiga bentuk ini mengalami transformasi dan disformasi dari bentuk stilasi daun, hal ini karena adanya pengaruh Islam yang tidak membolehkan menggambar mahluk hidup secara nyata dan sempurna, sehingga ketiga bentuk ini lebih 
abstrak atau tidak seperti kenyataan. Unsur kesungguhan relief pada panil di gapura paduraksa I adalah penonjolan pada relief ini terletak pada sebuah perjalanan manusia menuju ke alam kesucian, dimana pada bentuk relief ini dapat dibagi menjadi tiga bagian, bagian pertama simbol gajah merupakan gambaaran alam paling bawah (Bhurloka), bagian kedua bagian tengah gunung merupakan gambaran alam tengah atau alam roh-roh suci (Bhuwarloka), sedangkan bagian ketiga yaitu puncak gunung dan sepasang burung merak merupakan gambaran alam atas alam para dewa (Swarloka) atau dalam agama Islam yaitu jasmani, ruhani dan nurani.

Analisis nilai estetika relief pada panil di gapura Paduraksa I adalah, unsur garis melengkung yang mengalami transformasi dan disformasi menjadi bentuk sepasang belalai gajah, gunung dan sepasang burung merak merupakan perpaduan unsur agama Hindu dan Islam yaitu gambaran sebuah perjalan menuju kesucian dan juga merupakan gambaran pembagian alam yaitu alam bawah atau bumi dan isinya (Bhurloka) atau jasmani, alam tengah atau alam roh-roh yang suci (Bhuwarloka) atau ruhani dan alam atas alam para dewa alam ketuhanan (Swarloka) atau nurani.

\section{Nilai Estetika pada}

\section{Panil Gapura Paduraksa II}

Relief yang terdapat pada panil di gapura Paduraksa II berjumlah tujuh panil, fokus analisis pada panil 4 yang terdapat motif burung merak. Pada 4 terdapat tiga motif yaitu motif alam dengan bentuk gunung, motif fauna dengan bentuk burung merak dan motif teknologi dengan bentuk gapura.

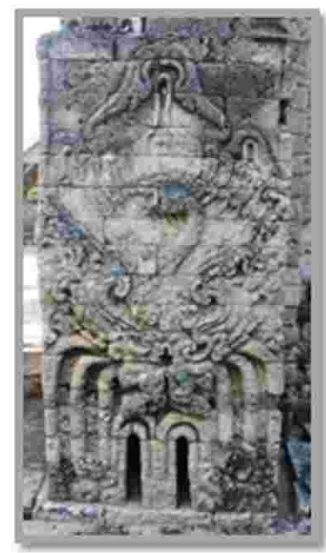

Gambar 11. Panil 4 (panil 4a dan panil 4b) (sumber foto koleksi pribadi 2018)

Unsur kesatuan relief pada panil 4 adalah unsur garis lurus dan garis lengkung yang lebih dominan membentuk unsur bangun melalui proses stilasi menjadi sebuah bentuk motif yaitu bentuk gunung bentuk gapura satu pintu, sepasang burung merak dan bentuk gapura dengan dua pintu dengan unsur tekstur alam, Perpaduan bentuk relief ini memberikan gambaran ruang semu tentang proses perjalanan manusia menuju kesucian dilihat dari bentuk paling bawah menuju bentuk atas.

Unsur kerumitan relief pada 4 adalah bentuk Relief ini merupakan perpaduan antara agama Hindu-Budha dengan Islam. Bentuk gunung dalam agama Hindu merupakan perwujudan mahameru tempat para dewa, sedangkan dalam Islam sebagai tempat sumber kehidupan lambang bumi dan air. Burung merak dalam agama Hindu, dipandang sebagai wahana dewa perang, yakni dewa Skanda atau Kartikeya, juga kendaraan Parwati ibunya, bentuk burung merak ini mengalami transformasi dari bentuk stilasi daun yang merupakan bentuk pengaruh dari agama Islam. Bentuk gapura dalam agama Hindu merupakan batas alam dunia dengan alam kayangan atau alam para dewa sedangkan dalam islam batas antara jasmani dan ruhani. Unsur kesungguhan relief pada panil 4 adalah penonjolan pada relief ini adalah gambaran 
Unsur kesatuan relief pada panil 4 adalah unsur garis lurus dan garis lengkung yang lebih dominan membentuk unsur bangun melalui proses stilasi menjadi sebuah bentuk motif yaitu bentuk gunung bentuk gapura satu pintu, sepasang burung merak dan bentuk gapura dengan dua pintu dengan unsur tekstur alam, Perpaduan bentuk relief ini memberikan gambaran ruang semu tentang proses perjalanan manusia menuju kesucian dilihat dari bentuk paling bawah menuju bentuk atas.

Unsur kerumitan relief pada 4 adalah bentuk Relief ini merupakan perpaduan antara agama Hindu-Budha dengan Islam. Bentuk gunung dalam agama Hindu merupakan perwujudan mahameru tempat para dewa, sedangkan dalam Islam sebagai tempat sumber kehidupan lambang bumi dan air. Burung merak dalam agama Hindu, dipandang sebagai wahana dewa perang, yakni dewa Skanda atau Kartikeya, juga kendaraan Parwati ibunya, bentuk burung merak ini mengalami transformasi dari bentuk stilasi daun yang merupakan bentuk pengaruh dari agama Islam. Bentuk gapura dalam agama Hindu merupakan batas alam dunia dengan alam kayangan atau alam para dewa sedangkan dalam islam batas antara jasmani dan ruhani. Unsur kesungguhan relief pada panil 4 adalah penonjolan pada relief ini adalah gambaran tentang ruang semu tentang perjalanan manusia menuju kesucian. Gapura dengan pintu dua merupakan batas antara alam dunia dengan alam adikodrati atau suatu simbolisasi dari akhir kehidupan manusia itu sendiri. Burung merak merupakan wahana atau kendaraan manusia menuju alam yang lebih tinggi yaitu bertemunya manusia dengan tuhannya, dalam perjalanan ini manusia masuk ke dalam alam roh suci atau ruhani. Gapura dengan pintu satu merupakan batas antara alam ruhani dan nurani. Gunung merupakan lambang dari perjalanan akhir manusia yaitu tempat bertemunya manusia dengan tuhan tau memasuki alam nurani atau swarlokaI alam paling atas.
Analisis relief pada panil 4 adalah unsur garis lurus dan garis lengkung yang lebih dominan yang mengalami stilasi dan transformasi membentuk sebuah unsur bangun menjadi sebuah motif gunung, gapura pintu satu, sepasang burung merak dan gapura dengan pintu dua dengan unsur tekstur alam. Relief ini merupakan perpaduan Hindu-Budha dengan Islam. Bentuk relief ini memberi gambaran tentang ruang semu yaitu perjalan manusia melalui pintu gerbang sebagai simbolisasi dari akhir kehidupan manusia sebagai tahapan pertama. Pada tahapan kedua manusia masuk ke alam adikodrati atau alam rohani tempat roh-roh yang suci. Burung merak atau amal ibadah sebagai wahana dalam perjalanan ini. pada tahapan ketiga manusia masuk lagi kepintu gerbang yang lebih sempit sebagai batas antara alam rohani menuju alam nurani atau alam Bhuwarloka menuju alam Swarloka. Pada tahapan ini merupakan tahapan terakhir dimana manusia akan bertemu denga sang pencipta

\section{KESIMPULAN}

Bentuk visual relief motif merak pada gapura Paduraksa I dan gapura Paduraksa II pada halaman pertama pesarean Sunan Sendang Duwur Paciran Lamongan merupakan relief dengan gaya floralistik yang didistorsikan, ditransformasikan dan didisformasikan sehingga berbentuk seperti mahluk hidup yang diabstrakkan. Bentuk-bentuk tersebut merupakan proses Islamisasi dari agama HinduBudha, dimana dalam agama Islam ada hadist yang menjadikan sumber penafsiran tentang pelarangan membuat atau menggambar mahluk hidup, sehingga bentuk visual dari relief yang berada di kompleks pesarean Sunan Sendang Duwur merupakan transformasi dari bentuk motif daun membentuk motif burung merak. Makna pada relief di kompleks pesarean Sunan Sendang Duwur pada intinya memberikan gambaran tentang bagaimanakah hubungan manusia dengan manusia, hubungan manusia dengan alam dan hubungan manusia dengan 
Tuhannya. Relief ini juga memberikan gambaran tentang simbol-simbol kehidupan yaitu tentang keberanian, pengetahuan, perlindungan, pengayom, kebesaran, kekuatan dan keadilan. Relief ini juga memberikan kita gambaran bahwasanya kompleks pesarean ini merupakan berkumpulnya roh-roh suci, tempat peristirahatan terakhir dari perjalanan manusia hingga manusia menghadap Tuhan dalam artian lain bahwasanya kawasan kompleks pesarean Sunan Sendang Duwur merupakan tempat suci/keramat, sehingga kita tidak boleh sembarangan melakukan tindakan atau perbuatan yang melanggar etika yang berlaku. Nilai-nilai estetika yang terkandung dalam reliefrelief di kompleks pesarean Sunan Sendang Duwur yaitu gambaran sebuah perjalan menuju kesucian dan juga merupakan gambaran pembagian alam yaitu alam bawah atau bumi dan isinya (Bhurloka) atau jasmani, alam tengah atau alam roh-roh yang suci (Bhuwarloka) atau ruhani dan alam atas alam para dewa alam ketuhanan (Swarloka) atau nurani. Nilai-nilai yang pada awalnya bersumber pada agama Hindu-Budha di Islamisasikan menjadi nilai yang bersumber pada Alquran dan Hadist, menjadi nilai-nilai estetika Jawa, walaupun pada hakekatnya pengaruh dari agama Hindu-Budha masih sangat kuat, baik itu dari bentuk visualnya, pemaknaannya dan nilai-nilai estetikanya.

\section{DAFTAR PUSTAKA}

\section{ARDIKA, I WAYAN.}

2007. Pusaka Budaya dan Pariwisata. Denpasar: Pustaka Larasan.

\section{Atmosudiro, Sumijati dkk.}

2008. Jawa Tengab Potret W arisan Budaya.

\section{Dharsono (SONY KarTiKa),}

HJ. SUARMI.

2007. Estetika Seni Rupa Nusantara. Surakarta: ISI Press Solo.

\section{Dillestone.}

2002. The Power Of Simbols. Yogyakarta: KANISIUS.

\section{DJELANTIK.}

1999. Estetika Sebuah Pengantar. Bandung: Masyarakat Seni Pertunjukan Indonesia arti.line.

GATOT, BAMBANG.

2012. "Kajian Estetika yang Beda Relief Candi J awa Timuran". JA! Vol. 2 No. 2. 2012. Pp. 14-27.

\section{GUSTAMI, SP.}

2008. "Nukilan Seni Ornamen Indonesia". Yogyakarta. Arindo Nusa Media.

\section{GuSTAMI, SP., SOEDARSONO., YunUS,} PAITA, PANGERAN.

2013. "Unsur Estetika Islam pada SeniHias Istana Raja Bugis".Jurnal Al-Ulum. Vol.12 No.1, Juni 2012 pp 35-52.

HASAN, MASRUR. Sejarah singkat Waliyullah R. Noer Rochmat Sunan Sending Duwur.

\section{Herusatoto, Budiono.}

1991. "Simbolisme dalam Budaya jawa". Yogyakarta:PT. Hanindita.

\section{ISMURDYAHWATI, IKA}

2011. "Babasa Rupa Relief Candi di Komplek Plaosan Lor". Panggung. Vol.21

No.4.2011 pp.368-374.

\section{RIZALI, NANANG.}

2012. "Kedudukan Seni dalam Islam". Jurnal Kajian Seni Budaya Islam. Vol.1 No.1 2012 pp 1-8. 
SANYOTO, EBDI, SADJIMAN.

2005. Dasar-dasat Tata Rupa dan Desain

(Nirmana). Yogyakarta: Arti Bumi Intaran.

\section{SETIAWAN, PINDI.}

2010. "Les difference du Nyeni: dalam Latar Bahasa Rupa dan Semiotik". Wimba. Vol 02 No. 1/2010. Pp. 1-18.

\section{SOEDARSO.}

1990. Tinjauan Seni Sebuah Pengantar Untuke Apresiasi Seni. Yogyakarta: Saku Dayar Sana.

\section{SOEDARSO.}

2006. Trilogi Seni Penciptaan Eksistensi dan Kegunaan Seni. Yogyakarta:

ISI Yogyakarta.

\section{SOEDARSONO.}

2000. Melacak Jejak Perkembangan Seni di Indonesia. Bandung: Arti.line.

\section{Soew asta, Muji.}

2014. "Menyingkap Latensi Eksotik Candi Sukuh Melalui Media Fotografi". Ornamen. Vol.11 No. 2. 2014 pp 138-146.

\section{SOEPRATNO.}

1983. "Ornamen Ukir Kayu Tradisional". Semarang: PT.Effhar.

\section{Subroto, GATOT, BAMBANG.}

2016. "Kajian Estetika Relief Candi di Jawa Timur" Yogyakarta: Graha Ilmu.

SuPriYATNO, ARI.

2014. 'Pande mas dan Perkembangan Gaya Seni Relief Pada Perbiasan Maa Klasik. Akbir diJawa".Ornamen. Vol. 11 No. 2. 2014 pp 97-107.

\section{SUNARYOARYO.}

2003. "Sengkelan Memet Dwina gasa Rasa Tunggal dalam Kaman Semiotik”. Wajana Seni Rupa Jurnal Seni Rupa dan Desain. Vol.3

No.6 2003 pp 1-14.

SuNARYO, ARYO.

2009. "Ornamen Nusantara. Kajian kbusus Tentang Ornamen Indonesia" Semarang: Dahara Prize.

SUNARTO,

2009. "Wayang Kulit Purwa" Yogyakarta: Arindo Nusa Media.

SunYoto, Agus.

2016. “Atlas Wali Songo". Jakarta: Pustaka Iiman dan LESBUMI PBNU.

SyAIFUL, USTAZI.

2011. Perjalanan Sunan Sendang Duwur Hingga Mengislamkan Pantura, menara Sunan Derajat, Edisi 6.

TJANDRASASMITA, UKA. 1975. "Islamic Antique of Sendang Duwur". Jakarta: Archaeolgical Foundation.

TJANDRASASMITA, UKA.

2009. "Arkeologi Islam Nusantara". Jakarta: PT. Gramedia. 